\title{
PEMBERIAN KOMPRES JAHE DALAM MENGURANGI NYERI SENDI PADA LANSIA DI UPT PSTW KHUSNUL KHOTIMAH PEKANBARU
}

\author{
Tri Siwi KN
}

\author{
Fakultas MIPA dan Kesehatan Universitas Muhammadiyah Riau \\ Email: trisiwinaning@gmail.com
}

\begin{abstract}
Gout and rheumatoid arthritis is a disease that is often encountered in the community, one of them on the elderly (the elderly) are characterized by pain that occurs repeatedly in the joints. Ginger compress can be used as a nonpharmacological measures to deal with the pain. This study aims to determine the effectiveness of ginger compress in reducing joint pain in the elderly in UPT PSTW Khusnul Khotimah Pekanbaru. This design of research is a quasi experiment with sampling total sampling with 16 respondents. Data collection tool using pain scale test pre and post administration of ginger compress. The research result shows that the average intensity of joint pain before and after the ginger compress is 2.500. The test results obtained statistical $p$ value $=0.000$ where $p<\alpha$ 0:05. this means that there are differences in average significant difference between the intensity of joint pain in the elderly before and after the ginger compress. Is expected to more elderly for routine use as a ginger compress nonpharmacological measures pain in the joints.
\end{abstract}

Keywords: Effectiveness, Compress ginger, joint pain

\section{PENDAHULUAN}

Gout dan arthritis rheumatoid merupakan salah satu penyakit yang sering ditemui dalam masyarakat, salah satunya pada kelompok lanjut usia (lansia) yang ditandai dengan nyeri yang terjadi secara berulang-ulang pada persendian. Keluhan ini biasanya akan berkurang dengan bantuan terapi baik secara farmakologis atau non farmakologis.

Kompres jahe dapat dijadikan tindakan nonfarmakologis untuk menangani nyeri. Menurut Haghighi M, Khalvat (2005), dalam Rusnoto (2014), berdasarkan hasil penelitian di Iran membuktikan jahe mempunyai efek yang sama dengan ibuprofen dalam mengatasi gejala osteoarthritis, termasuk nyeri.

Angka kejadian arthritis rheumatoid pada tahun 2008 yang dilaporkan oleh Organisasi Kesehatan Dunia WHO adalah mencapai $20 \%$ dari penduduk dunia yang telah terserang rematik, dimana 5-10\% adalah mereka yang berusia 5-20 tahun dan 20\% adalah mereka yang berusia 55 tahun (Wiyono, 2010).

Meskipun khasiat jahe untuk anti radang telah diketahui, namun efek dalam mengatasi rasa sakit pada manusia belum diketahui dengan pasti. Penelitian mengenai efektivitas penggunaan kompres jahe masih sangat terbatas dan terdapat hasil yang berbeda antara penelitian satu dengan yang lain. Oleh karena itu, perlu diteliti efektivitas pemberian kompres jahe dalam mengurangi nyeri sendi pada lansia dengan keluhan gouty dan arthritis rheumatoid (Ozgoli, G. Goli (2009), dalam Kallo (2014).

\section{METODOLOGI PENELITIAN}

Jenis Penelitian yang digunakan adalah kuasi eksperimen dengan teknik pengambilan sampel total sampling yang berjumlah 16 responden. Alat pengumpulan data menggunakan uji paired $t$ test dengan pre dan post pemberian kompres jahe pada area yang nyeri.

\section{Pengertian Nyeri}

Menurut Kozier \& Erb (2008) dalam Kallo (2014), nyeri adalah sensasi ketidak nyamanan yang dimanifestasikan sebagai penderitaan yang diakibatkan oleh persepsi jiwa yang nyata, ancaman, dan fantasi luka.

\section{Skala Nyeri}

Skala nyeri bourbonnais adalah salah satu cara mengukur tingkat nyeri berdasarkan 
penilaian objektif yang dilakukan oleh enumerator, yaitu:

1) Skala $0=$ tidak nyeri

2) Skala 1-3= nyeri ringan

Secara objektif subjek penelitian dapat berkomunikasi dengan baik, tindakan manual dirasakan sangat membantu.

3) Skala 4-6 = nyeri sedang

Secara objektif subjek penelitian mendesis, menyeringai, dapat menunjukkan lokasi nyeri dengan tepat dan dapat mendeskripsikan nyeri, subjek penelitian dapat mengikuti perintah dengan baik dan responsif terhadap tindakan manual.

4) Skala $7-9=$ nyeri berat

Secara objektif terkadang subjek penelitian dapat mengikuti perintah tapi masih responsif terhadap tindakan manual, dapat menunjukkan lokasi nyeri tapi tidak dapat mendeskripsikannya, tidak dapat diatasi dengan alih posisi, napas panjang, destruksi dll.

5) Skala $10=$ nyeri sangat berat (panik tidak terkontrol)

Secara objektif subjek penelitian tidak mau berkomunikasi dengan baik, berteriak, dan histeris. Subjek penelitian tidak dapat mengikuti perintah lagi, selalu mengejan tanpa dapat dikendalikan, menarik-narik apa saja yang tergapai, dan tidak dapat menunjukkan lokasi nyeri.

Jenis Ramuan jahe dan cara pemberian kompres pada area nyeri sendi (Chan, 2011)

a. Cuci bersih jahe 3-5 ruas

b. Kemudian, parut jahe dan tempatkan didalam mangkok

c. Aduk sampai menjadi seperti bubur

d. Balurkan parutan jahe tersebut pada sendi yang sakit selama \pm 15 menit

Kemudian sisa parutan jahe perbankan pada sendi yang bengkak.

\section{HASIL DAN PEMBAHASAN}

Hasil penelitian yang dilakukan tentang efektifitas kompres jahe terhadap penurunan nyeri sendi pada di UPT PSTW Khusnul Khotimah Pekanbaru dengan jumlah responden 16 orang responden dengan menggunakan analisis univariat dan analisis bivariat adalah sebagai berikut:

\section{A. Analisa Univariat}

Tabel 1. Distribusi frekuensi responden menurut umur pada penelitian pemberian kompres jahe terhadap penurunan nyeri sendi pada lansia di UPT PSTW Khusnul Khotimah Pekanbaru Tahun 2014

\begin{tabular}{cccc}
\hline No & $\begin{array}{c}\text { Kelompok } \\
\text { Umur }\end{array}$ & Frekuensi & $\begin{array}{c}\text { Persentase } \\
(\mathbf{\%})\end{array}$ \\
\hline $\mathbf{1}$ & $\begin{array}{c}\text { Lansia Awal } \\
(46-55 \text { tahun) } \\
\text { Lansia }\end{array}$ & $\mathbf{0}$ & $\mathbf{0}$ \\
$\mathbf{2}$ & $\begin{array}{c}\text { Menengah }(56- \\
65 \text { tahun) }\end{array}$ & $\mathbf{4}$ & $\mathbf{2 5}$ \\
$\mathbf{3}$ & $\begin{array}{c}\text { Masa Manula } \\
(>65 \text { tahun) }\end{array}$ & $\mathbf{1 2}$ & $\mathbf{7 5}$ \\
\hline & Jumlah & $\mathbf{1 6}$ & $\mathbf{1 0 0 \%}$ \\
\hline
\end{tabular}

Berdasarkan tabel di atas menunjukkan bahwa mayoritas umur responden yang mengalami keluhan nyeri sendi di UPT PSTW Khusnul Khotimah adalah masa manula (> 65 tahun) sebanyak $90 \%$.

Tabel 2. Distribusi frekuensi responden menurut jenis kelamin pada pemberian kompres jahe terhadap penurunan nyeri sendi pada lansia di UPT PSTW

Khusnul Khotimah Pekanbaru Tahun 2014

\begin{tabular}{cccc}
\hline No & Jenis Kelamin & Frekuensi & $\begin{array}{c}\text { Persentase } \\
(\%)\end{array}$ \\
\hline $\mathbf{1}$ & Laki-Laki & $\mathbf{6}$ & $\mathbf{3 7 , 5}$ \\
$\mathbf{2}$ & Perempuan & $\mathbf{1 0}$ & $\mathbf{6 2 , 5}$ \\
\hline & Jumlah & $\mathbf{1 6}$ & $\mathbf{1 0 0 \%}$ \\
\hline
\end{tabular}

Berdasarkan Tabel 2. di atas menunjukkan bahwa jenis kelamin yang menjadi responden sama yaitu laki-laki 50\% dan perempuan 50\%.

Tabel 3. Distribusi frekuensi responden menurut skala nyeri pre pemberian kompres pada penelitian pemberian kompres jahe terhadap penurunan nyeri sendi pada lansia di UPT PSTW Khusnul Khotimah Pekanbaru Tahun 2014

\begin{tabular}{cccc}
\hline No & Jenis Kelamin & Frekuensi & $\begin{array}{c}\text { Persentase } \\
(\mathbf{\%})\end{array}$ \\
\hline $\mathbf{1}$ & Nyeri ringan & 3 & 18,8 \\
$\mathbf{2}$ & Nyeri sedang & 9 & 56,3 \\
$\mathbf{3}$ & Nyeri berat & 4 & 25,0 \\
\hline & Jumlah & $\mathbf{1 6}$ & $\mathbf{1 0 0 \%}$ \\
\hline
\end{tabular}


Berdasarkan Tabel 3. di atas menunjukkan bahwa mayoritas responden sebelum diberikan kompres jahe berada pada kategori skala nyeri sedang sebanyak $56,3 \%$

Tabel 4. Distribusi frekuensi responden menurut skala nyeri post pemberian kompres pada penelitian pemberian kompres jahe terhadap penurunan nyeri sendi pada lansia di UPT PSTW Khusnul Khotimah Pekanbaru Tahun 2014

\begin{tabular}{cccc}
\hline No & Jenis Kelamin & Frekuensi & $\begin{array}{c}\text { Persentase } \\
(\mathbf{\%})\end{array}$ \\
\hline $\mathbf{1}$ & Tidak nyeri & 3 & 12,5 \\
$\mathbf{2}$ & Nyeri ringan & 9 & 56,3 \\
$\mathbf{3}$ & Nyeri sedang & 5 & 31,3 \\
\hline & Jumlah & $\mathbf{1 6}$ & $\mathbf{1 0 0 \%}$ \\
\hline
\end{tabular}

Berdasarkan Tabel 4. di atas menunjukkan bahwa mayoritas responden sesudah diberikan kompres jahe berada pada kategori skala nyeri ringan sebanyak $56,3 \%$

Tabel 5. Distribusi frekuensi responden menurut intensitas nyeri sebelum dan sesudah diberikan kompres jahe pada penelitian pemberian kompres jahe terhadap penurunan nyeri sendi pada lansia di UPT PSTW Khusnul Khotimah Pekanbaru Tahun

\begin{tabular}{|c|c|c|c|c|c|c|}
\hline $\mathbf{N}$ & $\begin{array}{c}\text { Intensit } \\
\text { as nyeri }\end{array}$ & $\begin{array}{c}\text { mea } \\
\text { n }\end{array}$ & $\begin{array}{c}\text { Media } \\
\text { n }\end{array}$ & $\begin{array}{c}\text { Mod } \\
\text { us }\end{array}$ & $\begin{array}{c}\text { Minimu } \\
\mathbf{m}\end{array}$ & $\begin{array}{c}\text { Maksimu } \\
\mathbf{m}\end{array}$ \\
\hline 1. & $\begin{array}{c}\text { Pre } \\
\text { kompre } \\
\mathrm{s}\end{array}$ & 2,06 & 2,00 & 2 & 1 & 3 \\
2. & $\begin{array}{c}\text { Post } \\
\text { kompre } \\
\text { s }\end{array}$ & 1,19 & 1,00 & 1 & 0 & 2 \\
\hline
\end{tabular}

Pada Tabel 5. menunjukkan rata-rata intensitas nyeri sendi sebelum diberikan kompres jahe adalah 2,06 dengan nila median 2.00. penurunan nyeri sendi yang dialami oleh lansia selama 15 menit dengan kompres jahe rata-rata intensitas nyeri menurun menjadi 1,19 dengan nilai median 1.00. jadi selisih rata-rata intensitas nyeri sendi sebelum dan setelah diberikan kompres jahe adalah sebesar 0,87 .

\section{B. Analisa Bivariat}

Analisa bivariat pada penelitian ini adalah untuk melihat perbandingan intensitas nyeri sendi sebelum dan sesudah diberikan kompres hangat pada lansia dengan uji paired sample $t$ test.
Tabel 6. Distribusi Rata-rata Penurunan nyeri sendi Responden hari pertama Pada Penelitian pemberian kompres jahe terhadap penurunan nyeri sendi pada lansia di UPT PSTW Khusnul Khotimah Pekanbaru Tahun 2014

\begin{tabular}{|c|c|c|c|c|c|}
\hline No & Metode & Mean & $\begin{array}{c}\text { Standar } \\
\text { deviasi }\end{array}$ & $\begin{array}{c}\text { Standar } \\
\text { error }\end{array}$ & $\begin{array}{c}\text { P } \\
\text { value }\end{array}$ \\
\hline 1 & $\begin{array}{l}\text { Pre post } \\
\text { kompres } \\
\text { jahe }\end{array}$ & 2.500 & 1.033 & 0,258 & 0.000 \\
\hline
\end{tabular}

Berdasarkan tabel di atas terlihat bahwa rata-rata intensitas nyeri sendi sebelum dan sesudah diberikan kompres jahe yaitu 2.500. hasil uji statistic didapat nilai $\mathrm{p}$ valuer $=0.000$ dimana $\mathrm{p}<\alpha$ 0.05. hal ini berarti bahwa terdapat perbedaan rata-rata yang signifikan antara intensitas nyeri sendi pada lansia sebelum dan sesudah diberikan kompres jahe.

Tabel 7. Distribusi Rata-rata Penurunan nyeri sendi Responden hari ketujuh Pada Penelitian pemberian kompres jahe terhadap penurunan nyeri sendi pada lansia di UPT PSTW Khusnul Khotimah Pekanbaru Tahun 2014

\begin{tabular}{|c|c|c|c|c|c|}
\hline No & metode & Mean & $\begin{array}{c}\text { Standar } \\
\text { deviasi }\end{array}$ & $\begin{array}{c}\text { Standar } \\
\text { error }\end{array}$ & $\begin{array}{c}\text { P } \\
\text { value }\end{array}$ \\
\hline 1 & $\begin{array}{c}\text { Pre -post } \\
\text { kompres } \\
\text { jahe }\end{array}$ & 1,625 & 0.806 & 0.202 & 0.000 \\
\hline
\end{tabular}

Berdasarkan Tabel 7. terlihat bahwa ratarata intensitas nyeri sendi sebelum dan sesudah diberikan kompres jahe yaitu 1.625. Hasil uji statistic didapat nilai $\mathrm{p}$ value $=0.000$ dimana $\mathrm{p}<\alpha$ 0.05. hal ini berarti bahwa pada hari kedelapan masih terdapat perbedaan rata-rata yang signifikan antara intensitas nyeri sendi pada lansia sebelum dan sesudah diberikan kompres jahe.

Penelitian Kalim (2013) dalam (2014) yang juga memperoleh hasil bahwa usia manula lebih banyak mengalami keluhan nyeri sendi dengan berbagai intensitas nyeri. Berdasarkan jenis kelamin, lansia yang paling banyak mengalami keluhan nyeri sendi adaah wanita yang berjumlah $62,5 \%$. Hal ini sesuai dengan teori Kertia Nyoman dalam Rusnoto (2014), bahwa semakin bertambah umur pada wanita akan mengalami menopause dan menyebabkan penurunan hormone estrogen sehingga beresiko 
mengalami penyakit asam urat yang akan menyebabkan keluhan nyeri pada persendian.

Menurut Perry \& Potter, (2006) dalam Aida (2013), pemberian kompres dingin dan hangat dapat digunakan untuk mengurangi nyeri dan peradangan nyeri. Pemberian kompres jahe biasa merupakan salah satu bentuk kompres dingin yang membantu mengurangi nyeri sendi.

Hal di atas sesuai dengan hasil penelitian Aida (2013), bahwa pemberian kompres dingin jahe juga mampu mengurangi nyeri sendi meskipun lebih baik jika menggunakan kompres hangat.

Demikian juga dengan hasil penelitian Rusnoto (2014), juga memperoleh hasil bahwa pemberian kompres jahe efektif untuk mengurangi nyeri pada penderita asam urat yang mana setelah dilakukan uji wilcoxon juga memperoleh nilai $\mathrm{p}=<0,05$.

Dengan demikian peneliti berpendapat bahwa pemberian kompres jahe sangat perlu disosialisasikan kepada semua kalangan khususnya kepada lansia karena selain harganya terjangkau juga sangat efektif dijadikan sebagai kompres pada area sendi yang mengalami sakit karena berbagai penyakit baik penyakit rematik, asam urat maupun keluhan sendi dengan penyakit lainnya.

\section{DAFTAR PUSTAKA}

Aida (2013). Perbedaan efektifitas kompres hangat dan kompres dingin terhadap skala nyeri pada klien gout di wilayah kerja Puskesmas Batang III Kabupaten Batang. Skripsi tidak diterbitkan. Prodi S 1 Keperawatan Sekoah Tinggi Ilmu Kesehatan Muhammadiyah Pekajangan.

Chan, (2011). Tanaman Berkhasiat Obat. Jakarta: Pustaka sunda kelapa

Dinas Kesehatan Republik Indonesia. (2012). Profil Dinas Kesehatan Di Indonesia. Diperoleh tanggal 04 April 2015 dari Http//www.depkes.go.id/kesehatan\%20i ndonesia\%202012.Pdf

Kallo (2014). Pengaruh kompres hangat terhadap penurunan skala nyeri pada penderita gouth arthritis di Wilayah Kerja Puskesmas bahu Manado.Artikel PSIK Universitas Sam Ratulangi Manado.

Nursalam. (2003). Konsep dan Penerapan Metodelogi Penelitian Ilmu Keperawatan, Jakarta: Salemba Medika

Notoatmodjo, S.(2003). Pendidikan Dan Perilaku Kesehatan. Jakarta: Rineka Cipta. (2007).Metodologi Penelitian. Jakarta: Rineka Cipta.

Rusnoto (2014). Pemberian kompres hangat memakai jahe untuk meringankan skala nyeri pada pasien asam urat di Desa Kedungwungu Kecamatan Tegowanu Kabupaten Grobogan. Stikes Muhammadiyah Kudus. Jawa Tengah. JIKK volume 6 No 1 Januari 2015 2939.

Sudoyo, A.W. dkk. (2007). Ilmu penyakit dalam. Jakarta: Interna Publishing 